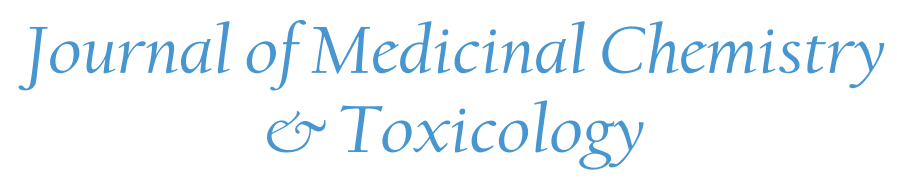

\title{
Comparative Analysis of Venom of Two Geographically Distinct European Adders
}

\author{
Vladimíra Tomečková ${ }^{*}$, Zuzana Andrejčáková2 ${ }^{2}$ Vladimír Petrilla ${ }^{2}$, Vladimír Komanický $^{3}$, Monika \\ Petrillová $^{4}$, Drahomíra Sopková ${ }^{2}$, Peter Korim ${ }^{5}$, Tomas Samuely ${ }^{3}$
}

\begin{abstract}
${ }^{1}$ Department of Medical and Clinical Biochemistry, Pavol Jozef Šafárik University in Košice, Faculty of Medicine, Slovak Republic.

${ }^{2}$ Department of Physiology, University of Veterinary Medicine and Pharmacy, Komenského 73, 041 81, Košice, Slovak Republic ${ }^{3}$ Institute of Physics, Pavol Jozef Šafárik University in Košice, Faculty of Science, Slovak Republic.

${ }^{4}$ Department of General Education Subjects, University of Veterinary Medicine and Pharmacy, Komenského 73, 041 81, Košice, Slovak Republic.

${ }_{5}^{5}$ Department of Environment, Veterinary legislation and Economics, University of Veterinary Medicine and Pharmacy, Komenského 73, 041 81, Košice, Slovak Republic.
\end{abstract}

*Corresponding authors: Vladimíra Tomečková, Department of Medical and Clinical Biochemistry, Pavol Jozef Šafárik University, Faculty of Medicine, Slovak Republic. Tr. SNP 1, 04011 Košice, Mobile: +421907438254;

Email: vladimira.tomeckova@upjs.sk

\begin{abstract}
Introduction: The study compares the venom of species, Vipera berus, from two geographically distinct areas. Individuals living in Slovakia produce larger volumes of venom in a venom gland compared to individuals living in Poland.

Methods: The complex molecular structure of individual native adder venom was recorded by synchronous fluorescence fingerprint, atomic force microscopy and protein electrophoresis.

Results: Fluorescence spectroscopy revealed differences in Slovak and Polish male and female structure of venoms and showed higher fluorescence intensity in Polish adder venom compared to Slovak adder venom. The similar pattern of venoms of snakes living in distinct area was observed by atomic force microscopy. The qualitative and quantitative protein differences in both albumin-like and globulin-like regions in adder venoms were detected by gel electrophoresis.

Conclusion: Our results exhibited differences in venom molecular structure of species Vipera berus from the distinct area.
\end{abstract}

Received Date: March 07, 2017

Accepted Date: April 25, 2017

Published Date: April 28, 2017

Citation: Tomečková, V., et al. Comparative Analysis of Venom of Two Geographically Distinct European Adders. (2017) J Med Chem Toxicol 2(2): $71-78$.

DOI: $10.15436 / 2575-808 X .17 .1397$

Keywords: Adder venom; Atomic force microscopy; Auto Fluorescence; Electrophoresis; Proteins; Synchronous Fluorescence Fingerprint; Vipera berus

\section{Introduction}

Species Vipera berus, the common European adder (Linnaeus 1758), is a wild venomous snake of the Palaearctic region ${ }^{[1]}$. Species Vipera berus is the only venomous snake living in Central and North Europe ${ }^{[2]}$. The adders are not considered to be extremely dangerous to humans ${ }^{[3]}$, however, they only bite when they are disturbed and feel threatened ${ }^{[4]}$.

This snake has a wide, flattened, triangular head which differs from the neck and the rest of the body. The head takes up from 4.5 to $5.5 \%$ of the body length. Lips are short and blunt, rounded at the tips. Eyes are relatively small with vertically elliptical pupils. The maximum length of the male body is $700 \mathrm{~mm}$, while female body length ranged between 800 and $1000 \mathrm{~mm}$ measured by Oliva., et $a l^{[5]}$. Kminiak and Kalúz ${ }^{[6]}$ observed smaller values of overall length of the body $\left(\mathrm{L}_{\text {tot }}=\right.$ longitudo totalis) in a population-based samples of male and female adders. The following results were recorded: $\mathrm{L}_{\text {tot }}=440 \mathrm{~mm}$, mean $=530 \mathrm{~mm}$, and maximum $=640 \mathrm{~mm}$ in 96 males; minimum $\mathrm{L}_{\text {tot }}=440 \mathrm{~mm}$, mean $=579 \mathrm{~mm}$, and maximum $=680 \mathrm{~mm}$ in 83 females investigated in the Slovak and Czech Republic ${ }^{[1]}$. 
The adder venom is a multi component mixture of substances which contains more than 100 different components ${ }^{[7]}$. More than $90 \%$ of the dry weight is composed of proteins comprising a variety of enzymes, nonenzymatic polypeptide toxins, and nontoxic proteins. It does not contain paralytic postsynaptic neurotoxins, cardiotoxins, myotoxins and necrotizing agents. PLA2 (phospholipase A2) is highly neurotoxic substance occurring in subspecies of the adder venom. PLA2 neurotoxins act presynaptically and can cause the innervation of the facial muscles.

Nonprotein compounds contain carbohydrates, metal ions (often part of glycoprotein, metalloprotein enzymes), lipids, free amino acids, nucleosides, and biogenic amines such as serotonin and acetylcholine, polysaccharides, low-molecular-weight substances and ions ${ }^{[8,9]}$.

Hemocoagulation and cytotoxic agents may be present in the adder venom, albeit in negligible quantities. Any venomous snake species contains clinically dangerous haemorrhagins and circulating toxins; if injected into the bloodstream they increase capillary permeability and cause haemorrhage. The constituent proteins of snake venom can affect the breakdown of tissue proteins and peptides.

The lethal dose for an adult human is estimated at $15-20 \mathrm{mg}$ of adder venom, which is similar to the venom of cobra Naja $n a j a^{[7]}$. L-amino acid oxidases originating from Vipera berus venom that can induce apoptosis and have ability to cause aggregation of platelets in conjunction with haemorrhagic effect ${ }^{[1,11]}$. The hyaluronidase, originating from the family Viperidae, enhances the toxicity of venom by increasing the influx of systemic toxins ${ }^{[12]}$.

The fluorescence properties of the particular venom organic components are the consequence of their molecular structure and the presence of endogenous fluorophores e.g. aromatic amino acids, proteins, nucleosides, vitamins, and coenzymes ${ }^{[13,14]}$. All proteins and amino acids have not been revealed, yet. To understand the functions of proteins at a molecular level, it is often necessary to determine their structure. This is the topic of the scientific field of structural biology, which employs several analytical techniques such as X-ray crystallography, NMR crystallography, NMR spectroscopy, MS spectroscopy, HPLC, dual polarization interferometry, and other techniques.

Adders usually occur at high altitudes over 400 meters above sea level, however, our identified individuals were captured also at a lower altitude (115 - 130 meters above sea level) in Poland. Therefore, the aim of our study was to compare craniometric measurements of the adder of two distinct geographical areas (Slovak Republic and Poland), focusing on the length of fangs, the amount of venom in the venom glands, and then the findings were compared with the differences among adder venoms using fluorescence spectroscopy, atomic force microscopy, and electrophoresis of proteins. These unconventional methods were used in our previous research in a number of different African mambas of genus Dendroaspis ${ }^{[15]}$ and two species of African cobras Naja ashei and Naja nigricollis ${ }^{[16]}$ where we examined the components of snake venoms.

\section{Materials and Methods}

\section{Venom Samples Preparation Technique}

The venom of Vipera berus (male and female from Slovakia and Poland) was collected into the plastic vial ${ }^{[15,16]}$, stored in the transport cryogenic microtubes under liquid nitrogen $\left(\mathrm{t}=-196{ }^{\circ} \mathrm{C}\right)$ and kept in deep freezer $\left(\mathrm{t}=-70{ }^{\circ} \mathrm{C}\right)$. The volumes of obtained venom in individuals were too small (only 25 micro liters, in drops). The venom of 4 individuals was mixed within the same population-gender group of the same geographical area. The venom was centrifuged (Centrifuge EBA 21, HETTICH GmbH \& Co. $\mathrm{KG}$, Tuttlingen, Germany) for $5 \mathrm{~min}$ at $600 \mathrm{xg}$ prior each analysis. The $\mathrm{pH}$ of adder venom was determined by using potentiometry on Twin compact pH metre B-212 (HORIBA Europe GmbH, Sulzbach, Germany).

\section{Fluorescent Analysis of Crude Venom}

Native venom samples from the adders were analyzed by Synchronous Fluorescent Fingerprint (SFF) and simple synchronous excitation fluorescence spectra $\Delta=70 \mathrm{~nm}$ of SFF in a quartz cuvette $(500 \mu \mathrm{L})$ on a Perkin-Elmer LS 55 (Waltham, Massachusetts, USA) spectrophotometer with instrument settings and measurement conditions at scan speed of $1200 \mathrm{~nm} / \mathrm{s}$, slits were set to 5 $\mathrm{nm}$ for both excitation and emission wavelengths at laboratory temperature. Each synchronous excitation spectrum was measured from $\lambda=200$ to $\lambda=600 \mathrm{~nm}$.

The resulting SFF was created from 20 scans of simple synchronous excitation spectrum at different excitation wavelengths with constant distance between individual spectra ${ }^{[20]}$ called increment. The data were processed by WinLab software (PerkinElmer, Waltham, Massachusetts).

\section{Atomic Force Microscopy (AFM) of Crude Venom}

The venom $(25 \mu \mathrm{L})$ of Vipera berus was analysed on the microscopic slide by atomic force microscopy (ICON, Bruker, Berkeley, California, USA) in the tapping mode with silicon tips (Mikro Masch, NSC35 series), and with radius of curvature $\sim 10$ $\mathrm{nm}$. The results were processed by Nanoscope software (Bruker, Berkeley, California, USA).

\section{Atomic Absorption Spectrophotometry of Crude Venom}

The total protein concentration of adder venom was measured at $\lambda_{\text {abs }}=540 \mathrm{~nm}$ by using a diagnostic kit (Randox, Crumlin, United Kingdom) on automatic biochemical analyser Alizé (Lisabio, Pouilly-en-Auxois, France). 


\section{Electrophoresis of Crude Venom}

The proteins in adder venom $(10 \mu \mathrm{L})$ was separated from crude venom by using Hydragel 15 protein kit (Ecomed, Žilina, Slovak Republic) on agarose gels $(\mathrm{pH}=9.2)$ by electrophoretic Hydrasys equipment (Sebia, Lisses, France). The fractions were visualized by $0.4 \mathrm{~g} / \mathrm{dL}$ Amido Black. The dried gels were evaluated by using Phoresis software (Version 5.50, 2009, Sebia, Lisses, France) on Epson perfection V 700 Photo $(\lambda=570 \mathrm{~nm})$ and obtained results were visualized in electrophoretograms and densitometric curves.

\section{Results}

\section{Adder venom comparisons}

The venom in male snakes showed maximal intensity of fluorescence spectra in the lipophilic region (at lower wavelength) and in the hydrophilic region (at longer wavelengths). The venom in female snakes exhibited the highest intensity of fluorescence at longer wavelengths (Figure 1). Each venom revealed an acidic $\mathrm{pH}$ value $(\mathrm{pH}=5.5)$. The SFF (Figures $1 \mathrm{~B}$ and $\mathrm{D})$ showed a similar structure and position of fluorescence centers of a venom in male snakes from Slovakia $(70 / 289 \mathrm{~nm}, \mathrm{~F}=546)$ and from Poland $(50 / 294 \mathrm{~nm}, \mathrm{~F}=573)$. However, detailed examination of the fluorescent centres showed differences. Female adder (Figures $1 \mathrm{~A}$ and C) from Slovakia $\left(\Delta 50 / \lambda_{\text {ex }}=312 \mathrm{~nm}, \mathrm{~F}=1000\right)$ and Poland $\left(\Delta 50 / \lambda_{\mathrm{ex}}=303 \mathrm{~nm}, \mathrm{~F}=1000\right)$ showed different structures of SFF but had similar localization of centers with maximal fluorescence intensity (Figure1).
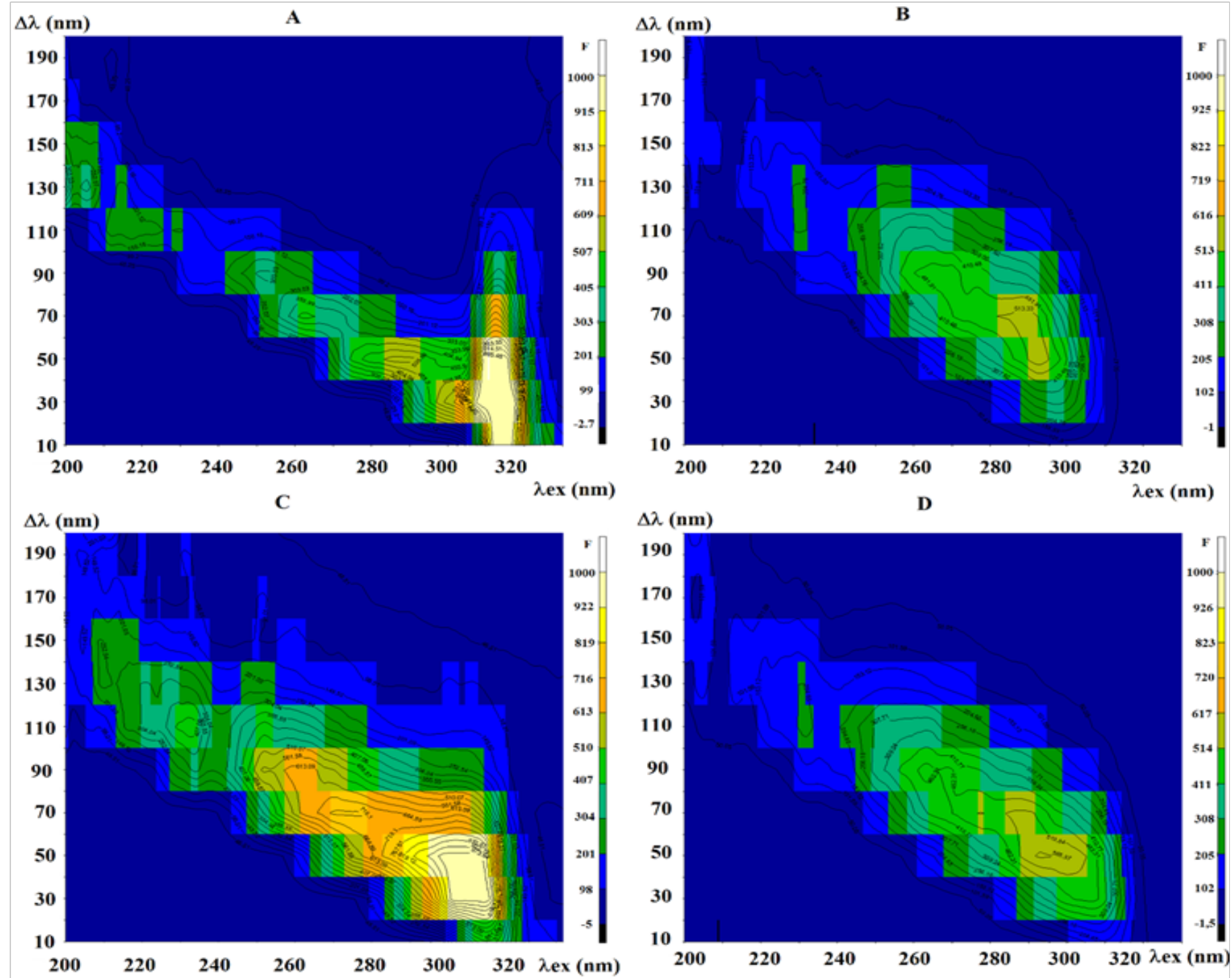

Figure 1: The synchronous fingerprints and fluorescence spectra of adder venom (Vipera berus): (A) Female from Slovakia (B) Male from Slovakia (C) Female from Poland (D) Male from Poland. Constant differences between emission and excitation wavelengths correspond to the delta lambda $(\Delta \lambda)$.

A horizontal cut of individual samples at $(\Delta 70 \mathrm{~nm})$ of SFF revealed simple spectra of SFF and showed differences in the structure of individual adder venom (Table 1; Figure 2). The venom from female snakes from Slovakia showed two maxima (Table 1; Figure 2 A), while the venom from male snakes also from Slovakia exhibited only one maximum (Table 1 ; Figure 2 B) at $\lambda_{\text {ex }}=$ 
$289 \mathrm{~nm}(\mathrm{~F}=546)$ that was similar to the venom from male snakes from Poland (Table 1; Figure $2 \mathrm{D})$ at $\lambda_{\mathrm{ex}}=289 \mathrm{~nm}(\mathrm{~F}=527)$. The venom from the female snake from Poland visualized two maxima (Table 1; Figure $2 \mathrm{C}$ ) with higher fluorescence intensity than the venom from female snakes from Slovakia.

Table 1: The comparison of fluorescence maxima on the profiles of synchronous excitation spectrum of Vipera berus venom.

\begin{tabular}{|c|c|c|c|c|c|c|c|c|}
\hline \multirow{2}{*}{ Maxima } & \multicolumn{2}{|c|}{ Female SK } & \multicolumn{2}{c|}{ Male SK } & \multicolumn{2}{c|}{ Female PL } & \multicolumn{2}{c|}{ Male PL } \\
\cline { 2 - 9 } & $\boldsymbol{\lambda}_{\max }(\mathbf{n m})$ & $\mathbf{F}$ & $\boldsymbol{\lambda}_{\max }(\mathbf{n m})$ & $\mathbf{F}$ & $\boldsymbol{\lambda}_{\max }(\mathbf{n m})$ & $\mathbf{F}$ & $\boldsymbol{\lambda}_{\max }(\mathbf{n m})$ & $\mathbf{F}$ \\
\hline 1 & 263 & 420 & 289 & 546 & 271 & 726 & 289 & 527 \\
\hline 2 & 313 & 641 & & & 303 & 651 & \\
\hline
\end{tabular}

$\lambda_{\max }$, Maximal excitation wavelength at constant $\Delta \lambda 70 \mathrm{~nm}$ difference between emission and excitation wavelengths; F, Intensity of fluorescence; SK, Slovakia; PL, Poland.

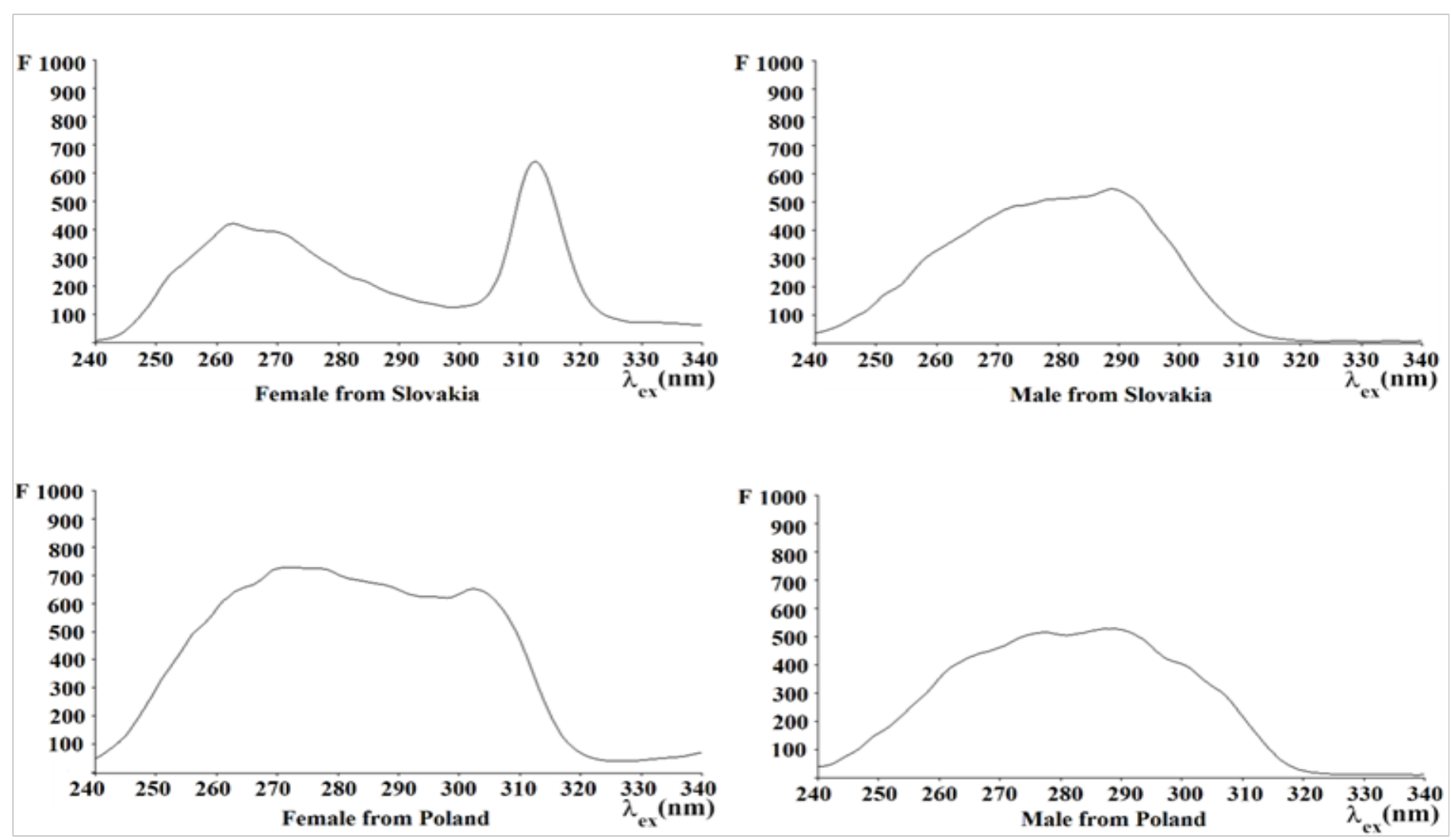

Figure 2: Fluorescence intensity of the simple synchronous excitation spectra in venom (Vipera berus) measured at the delta lambda $(\Delta \lambda=70$ $\mathrm{nm}) . \Delta \lambda=70 \mathrm{~nm}$ corresponds to the constant difference between emission and excitation wavelengths; $\lambda_{\text {ex }}(\mathrm{nm})$ is excitation wavelength and $\mathrm{F}$ is intensity of fluorescence.

The structure of selected adder crude venom (Figure 3) was investigated and compared by Atomic Force Microscopy (AFM). The present results of AFM showed that all individuals (male and female snakes living in Slovakia and Poland) have the similar pattern of venom. Clusters of globular particles with a diameter of $10 \mathrm{~nm}$ were associated into formations with irregular shapes and diameter of $50 \mathrm{~nm}$. The adder venom obtained from male specimens $(\mathrm{r}=0.5 \mathrm{~nm})$ and female specimens $(\mathrm{r}=0.4 \mathrm{~nm})$ showed minimum differences in surface roughness between the genders living in Slovakia and Poland.

All adder venoms showed different concentration of total proteins. Separation of proteins resulted in qualitative and quantitative differences in fractions of proteins (Table 2). The highest concentration of total protein was recorded in the female snakes from Slovakia. The lowest protein content was determined in male snakes from Slovakia on the contrary with the male snakes from Poland which showed higher concentration of protein in comparison with the female snakes from Poland. The highest number of globulin-like fractions was recorded in male snakes from Slovakia $(\mathrm{n}=8$; Table 2; Figure $4 \mathrm{~B})$ and female snakes from Slovakia (n = 7; Table 2; Figure 4 A) in comparison with male snakes from Poland ( $\mathrm{n}=5$; Table 2; Figure $4 \mathrm{D})$ and female snakes from the same country $(\mathrm{n}=5$; Table 2; Figure $4 \mathrm{C})$. The lowest albumin-like fractions showed female snakes from Poland ( $\mathrm{n}=0$; Table 2; Figure 4 C) and male snakes from Slovakia $(n=1$; Table 2; Figure 4 D) contrary to female snakes from Slovakia ( $n=2$; Table 2; Figure 4 A) and male snakes from Poland $(n=2$; Table 2; Figure 4 B) with similar number of albumin-like fractions. 

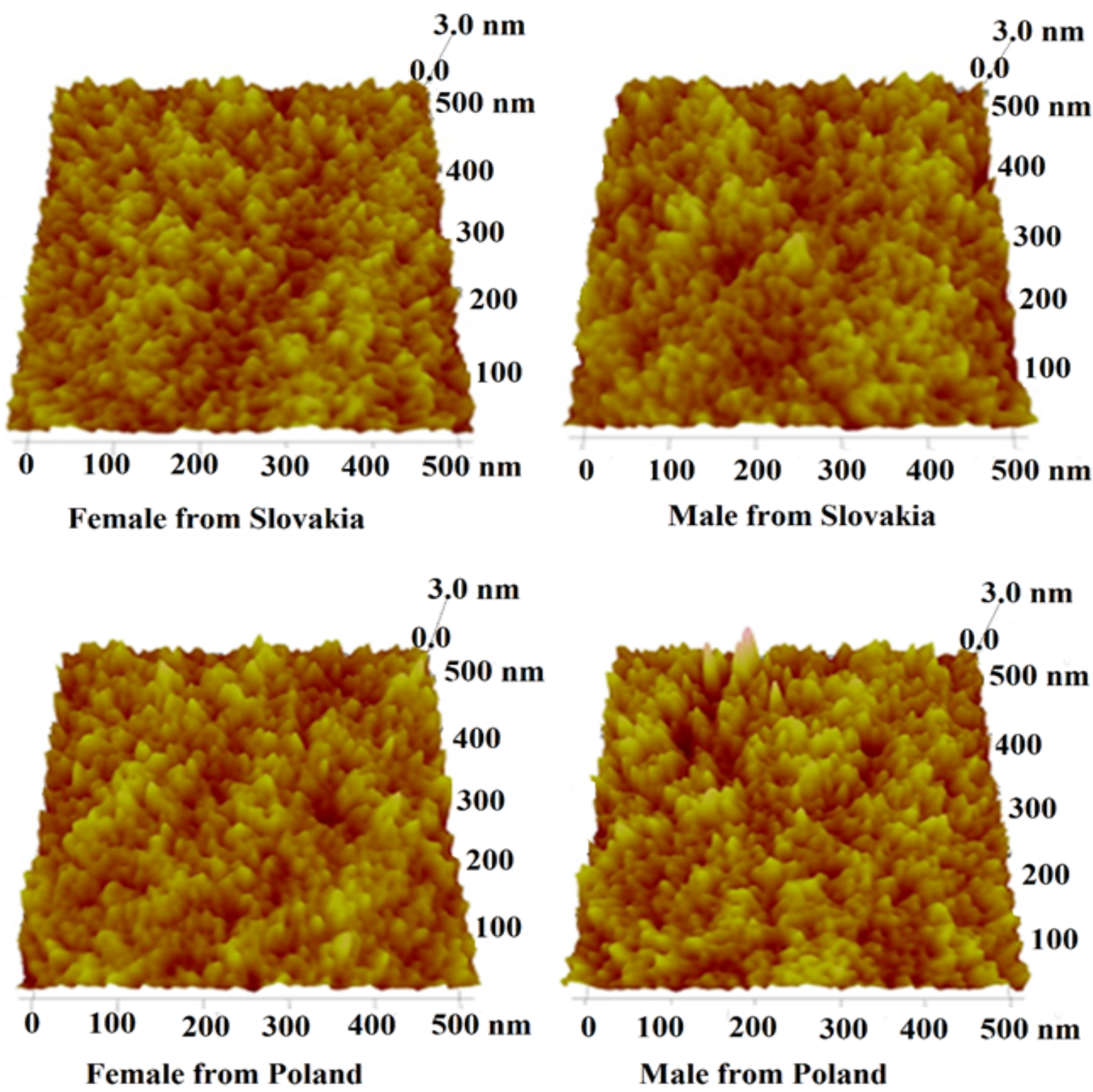

Figure 3: Atomic force microscopy of adder venom (Vipera berus). " $0 \mathrm{~nm}$ " and " $3 \mathrm{~nm}$ " indicates (z axis) minimal and maximal height of each globule.

Table 2: Total protein content and the results of electrophoretic separation of proteins from adder venoms.

\begin{tabular}{|c|c|c|c|c|c|}
\hline \multirow{2}{*}{\multicolumn{2}{|c|}{ Separated fractions }} & \multicolumn{4}{|c|}{ The concentration of proteins $(\mathrm{g} / \mathrm{L})$} \\
\hline & & \multirow{2}{*}{$\begin{array}{c}\text { Female SK } \\
3.2 \\
\end{array}$} & \multirow{2}{*}{$\begin{array}{c}\text { Male SK } \\
1.7\end{array}$} & \multirow{2}{*}{$\begin{array}{c}\text { Female PL } \\
2.5 \\
\end{array}$} & \multirow{2}{*}{$\begin{array}{c}\text { Male PL } \\
3.2 \\
\end{array}$} \\
\hline \multirow{8}{*}{ Globulin-like fractions } & 1 & & & & \\
\hline & 2 & 1.9 & 0.8 & 12.5 & 12.9 \\
\hline & 3 & 12 & 1.6 & 25.1 & 25.4 \\
\hline & 4 & 28.9 & 7.4 & 6.5 & 8.5 \\
\hline & 5 & 13.3 & 19.7 & 4.7 & 6.2 \\
\hline & 6 & 4 & 6.8 & & \\
\hline & 7 & 0.3 & 7.4 & & \\
\hline & 8 & & 0.5 & & \\
\hline \multirow{2}{*}{ Albumin-like fractions } & A1 & 1.2 & 3.3 & & 2.1 \\
\hline & $\mathrm{A} 2$ & 4 & & & 0.8 \\
\hline Total protein & & 68.7 & 49.2 & 51.3 & 59.1 \\
\hline
\end{tabular}

SK, Slovakia; PL, Poland. 


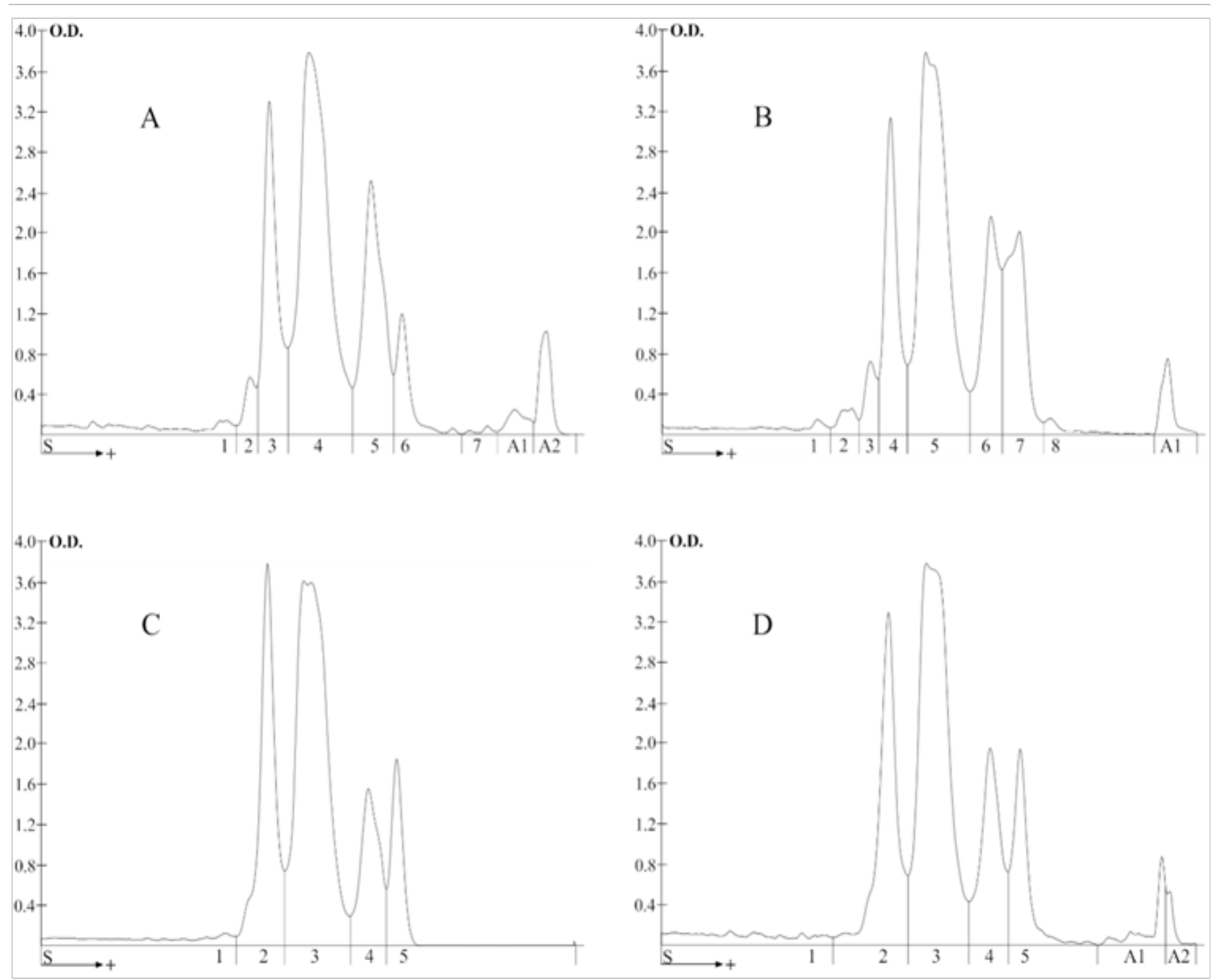

Figure 4: Gel photograph shows the electrophoretic separations of the venom sample of Vipera berus of: (A) female from Slovakia, (B) male from Slovakia, (C) female from Poland, (D) male from Poland. S, start (junction between the stacking and separation gels); O.D., optical density; the $\mathrm{x}$ axis represents the scanned area of the gel strip; 1-8, labelling of globulin-like fractions; A1-A2, labelling of albumin-like fractions.

\section{Discussion}

The mixture of organic fluorophores present in natural snake venom is a multi-fluorescent viscous liquid and can be studied by Fluorescence Spectroscopy (SFF) and atomic force microscopy as new alternatives for monitoring and the first characterization of adder venom structure ${ }^{[16,17]}$. The main organic fluorophores responsible for the final fluorescence of SFF include enzymes, amino acids and proteins. Obviously, serotonine, nucleosides and biogenic amines can influence the fluorescence intensity. Most venom contains fluorescent 1 - amino acid oxidase with prosthetic cofactor FMN or FAD ${ }^{[18]}$ which is responsible for the yellow colour of many types of venom. It is known from the literature that riboflavin (vitamin B2) and cofactors (FMN and FAD) are active fluorophores $^{[13,14]}$.

Electrophoresis is a specific method with widespread use ${ }^{[19]}$. According to Oh-Ishi and Maeda ${ }^{[20]}$ the advantage of using this method is the high permeability for substances with high molecular weight, because it has a larger pore diameter compared to polyacrylamide gel. Our work was also focused on the comparison of electrophoretograms of adder venoms from male and female snakes. Gel electrophoretograms (Figure. 4) indicated the differences between qualitative and quantitative protein fractions in both albumin-like and globulin-like regions in adder venom. Similar nomenclature was also used in the study of Göçmen., et al ${ }^{[21]}$. They studied and compared the differences in morphology and electrophoretic types of venom proteins in compared individuals of Levantine vipers, Macrovipera lebetina (Linnaeus 1758), from Cyprus and southern Anatolia. They made a conclusion that the southern Anatolian population should not be appointed as the exclusive subspecies of M. l. lebetina that lives in Cyprus. Arikan., et $a l^{[22]}$. studied the venom proteins of Vipera ammodytes (Linnaeus 1758), and Vipera kaznakovi (Nikolsky 1909) and they revealed considerable differences between mentioned species using polyacrylamide gel electrophoresis. The snake bites could cause a wide range of pathophysiological effects for which it is probably responsible complex molecular structure originating from snake ven$\mathrm{om}^{[23]}$. Our results of all adder venoms showed different concentration of total proteins and electrophoretic separation resulted in 
qualitative and quantitative differences in fractions of proteins (Table 2, Figure 4). The highest concentration of total protein was recorded in the female snakes from Slovakia. The lowest protein content was determined in male snakes from Slovakia on the contrary with the male snakes from Poland which showed higher concentration of protein in comparison with the female snakes from Poland. The amount of protein in snake venom can be affected by various factors which include sex, feed, genetic factors, habitat and distribution area of snakes ${ }^{[24]}$.

\section{Conclusion}

Differences between species Vipera berus studied from distinct areas showed that individuals living in higher altitudes in Slovakia in comparison with those living in lower altitudes in Poland were observed. The different composition of all studied crude adder venoms was determined by fluorescence spectroscopy, atomic force microscopy and protein electrophoresis that might be influenced by various biotopes. These methods can be important tools for the analytical identification of novel and unknown venoms taken from different species of snakes.

Conflicts of Interest: The authors declare no conflicts of interest.

Acknowledgments: This research was funded by the project VEGA No. 1/0409/15; VEGA No. 1/0476/16 and grant ITMS under contract number 26220120005 .

\section{References}

1. Baruš, V., Kminiak, M., Král, B., et al. Plazi-Reptilia, 1st ed. (1992) Academia: Praha, Czech Republic 222.

2. Isailovic, J.C., Vogrin, M., Corti, C. et al. 2009 Vipera berus. The IUCN Red List of Threatened Species Version 2014.1.

3. Mallow, D., Ludwig, D., Nilson, G. True Vipers: Natural History and Toxinology of Old World Vipers. (2003) Krieger Publishing Company 410.

Others

4. Warrell, D.A. Treatment of bites by adders and exotic venomous snakes. (2005) BMJ 331(7527): 1244-1247.

Pubmed | Crossref | Others

5. Oliva, O., Hrabě, S., Lác, J. Stavovce Slovenska 1 Ryby, obojživelníky a plazy, 1st ed.; (1968) Slovenská akadémia vied: Bratislava, Slovak Republic 389.

6. Kminiak, M., Kalúz., S. Evaluation of sexual dimorphism in snake (Ophidia, Squamata) based on external morphological characters. (1983) Folia Zoologica 32: 259-270.

7. Valenta, J. Jedovatí hadi: Intoxikace, terapie, 1st ed. (2008) Galén: Praha, Czech Republic 401.

8. Wang, S.Y. Liu, Q.L. Xu, X.L. et al. Synchronous Fluorescence Spectra of Fibrinolytic principle from snake venom of Agkistrodon Acutus. (2001) Spectroscop Lett 34: 427-435. Crossref

9. Mackessy, S.P. Biochemistry and pharmacology of colubrid snake venoms. (2002) J Toxicol Toxin Rev 21(1-2): 43-83.

Crossref $\mid$ Others

10. Du, X.Y., Clemetson, K.J. Snake venom L-amino acid oxidases. (2002) Toxicon 40(6): 659-665.

Pubmed | Crossref

11. Samel, M., Vija, H., Rönnholm, G., et al. Isolation and characterization of an apoptotic and platelet aggregation inhibiting L-amino acid oxidase from Vipera berus berus (common viper) venom. (2006) Biochim Biophys Acta 1764(4): 707-714.

Pubmed | Crossref | Others

12. Kang, T.S., Georgieva, D., Genov, N., et al. Enzymatic toxins from snake venom: structural, characterization and mechanism of catalysis. 2011 FEBS J 278: 4544-4576.

Pubmed | Crossref | Others

13. Koziol, B., Markowicz, M., Kruk, J., et al. Riboflavin as a source of autofluorescence in Eisenia fetidacoelomocytes. (2006) Photochem Photobiol 82(2): 570-573.

Pubmed | Crossref 
14. Jayapaul, J., Arns, S., Lederle, W., et al. Riboflavin carrier protein-targeted fluorescent USPIO for the assessment of vascular metabolism in tumors. (2012) Biomaterials 33(34): 8822 8829.

Pubmed | Crossref | Others

15. Andrejčáková, Z., Petrilla, V., Tomečková, V., et al. New approaches in monitoring venom of genus Dendroaspis. (2015) Spectro Lett 48(6): 462-472.

Crossref

16. Petrilla, V., Tomečková, V., Komanický, V., et al. Fluorescent Profiling of Venom Selected Cobra Species. (2014) Spectro Lett 47(1): 1-5.

Crossref

17. Tomečková, V., Lichardusová, L., Komanický, V., et al. The spectrometric monitoring of water purification by natural alternatives. (2012) Spectro Lett 45(6): 447-451.

Crossref

18. Stocker, K.F. Medical use of snake venom proteins, 1st ed. (1990) CRC Press 280.

Others

19. Ostapchenko, L., Savchuk, O., Burlova-Vasilieva, N. Enzyme electrophoresis method in analysis of active components of haemostasis system. (2001) Advanc Biochem Biophys 2(1): 20-26.

Crossref $\mid$ Others
20. Oh-Ishi, M., Maeda, T. Disease proteomics of high-molecular-mass proteins by two-dimensional gel electrophoresis with agarose gels in the first dimension (Agarose 2-DE). (2007) J Chromatogr B Analyt Technol Biomed Life Sci 849(1-2): 211222.

Pubmed | Crossref

21. Göçmen, B., Arikan, H., Marmer, A., et al. Morphological, Hemipenial and Venom Electrophoresis Comparisons of the Levantine Viper, Macrovipera lebetina (Linnaeus, 1758), from Cyprus and Southern Anatolia. (2006) Turkish Journal of Zoology 30: $225-234$

Others

22. Arikan, H., Göçmen, B., İğc1, N., et al. Age-dependent variations in the venom proteins of Vipera kaznakovi Nikolsky, 1909 and Vipera ammodytes (Linnaeus, 1758) (Ophidia: Viperidae). (2014) Turk J Zool 38: 216-221.

Crossref $\mid$ Others

23. Chérifi, F., Rousselle, J.C., Namane, A., et al. CCSV-MPase, a novel procoagulant metalloproteinase from Cerastes cerastes venom: purification, biochemical characterization and protein identification. (2010)

Protein J 29(7): 466-474.

Pubmed | Crossref | Others

24. Francischetti, I.M., Gombarovits, M.E., Valenzuela, J.G., et al. Intraspecific variation in the venoms of the South American rattlesnake (Crotalus durissus terrificus). (2000) Comp Biochem Physiol C Toxicol Pharmacol 127(1): 23-36.

Pubmed | Crossref
Ommega Online Publisher

Journal of Medicinal Chemistry \& Toxicology

Short Title : J Med Chem Toxicol
E-mail: medchemtoxic@ommegaonline.org

website: www.ommegaonline.org 